Article

\title{
Feeding habits of Mustelus henlei on the western coast of Baja California Sur, México
}

\author{
Hábitos alimentarios de Mustelus henlei en la costa Occidental de Baja California Sur, México
}

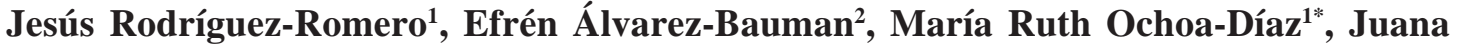 \\ López-Martínez ${ }^{3}$ and Minerva Maldonado-García ${ }^{1}$
}

\begin{abstract}
${ }^{1}$ Centro de Investigaciones Biológicas del Noroeste, S.C. Apdo. Postal 128 La Paz, B.C.S. C.P. 23000 , México. jrodri04@cibnor.mx, minervam04@cibnor.mx; 'Corresponsal author. mrochoa@cibnor.mx

${ }^{2}$ Centro de Estudios Superiores, Estado de Sonora, Rosales No. 189 Col. Centro Hermosillo, Sonora, México

${ }^{3}$ Centro de Investigaciones Biológicas del Noroeste, S.C. Km 2.35 Carretera a Las Tinajas, S/N Colonia Tinajas, Guaymas, Sonora, C. P. 85460, México.jlopez04@cibnor.mx

Resumen.- El tiburón musola parda Mustelus henlei forma parte de una importante pesquería comercial en la costa occidental de Baja California Sur, México. Sin embargo, se han realizado muy pocos trabajos sobre biología, reproducción y alimentación de esta especie. Nuestro estudio, es el primer trabajo que se realiza en esta especie en la plataforma continental (14 $\mathrm{m}$ a $250 \mathrm{~m}$ de profundidad) de B.C.S. Mediante un análisis taxonómico, se identificaron un total de 24 tipos de presas, de los cuales 15 fueron crustáceos, 6 peces y 3 cefalópodos. De acuerdo al índice de importancia relativa (IIR) la presa principal fue la langostilla Pleuroncodes planipes $(81,4 \%)$, seguida de la materia orgánica no identificada (MONI) (15,7\%), la macarela Scomber japonicus $(0,94 \%)$ y los restos de peces $(0,84 \%)$. En el análisis de importancia de presas por sexos, se encontró que tanto en hembras como en machos, la langostilla P. planipens fue la presa más importante, después MONI y S. japonicus. Las especies importantes en la dieta del tiburón que se encontraron en zonas más profundas (120 a $150 \mathrm{~m}$ ) a bordo del crucero BIP XII, fueron similares a las encontradas en la localidad más somera (14-40 m) de Punta Lobos, siendo la presa dominante la langostilla y también el MONI. De acuerdo al Índice de Levin M. henlei es considerado un tiburón especialista. Se observó una superposición de dieta por sexo, área y talla. Con el análisis SIMPER se muestró una baja similitud entre las dietas, con valor de significancia reducida entre sexos, tallas y áreas. De acuerdo a la prueba ANOSIM no se encontraron diferencias significativas. El conocer que $M$. henlei presenta un comportamiento especialista puede ayudar no sólo a la conservación de la especie, sino de su hábitat y de los organismos que se encuentran en él y que son de vital importancia para el tiburón.
\end{abstract}

Palabras clave: Contenido estomacal, superposición de dieta, especialista, Punta Lobos, Baja California Sur, México

\begin{abstract}
The Brown smooth-hound Mustelus henlei is part of an important commercial fishery on the western coast of Baja California Sur (BCS), Mexico. However, very few studies have been performed on the feeding and reproduction biology of these sharks in Mexico. Our study is the first work focusing on this species on the western shelf (14 $\mathrm{m}$ to $250 \mathrm{~m}$ in depth) of B.C.S. We identified a total of 24 types of prey contents in the stomachs of $M$. henlei: 15 crustaceans, 6 fish, and 3 cephalopods. According to the index of relative importance (IRI) the main prey items for $M$. henlei was the pelagic red crab Pleuroncodes planipes (81.4\%), followed by unidentified organic material (UOM) (15.7\%), the mackerel Scomber japonicus $(0.94 \%)$, and fish remains $(0.84 \%)$. Conducting a prey analysis considering sex of $M$. henlei, P. planipes was the most important prey in both females and males, followed by UOM, and S. japonicus. Sharks found in deeper areas (120-150 m) and those caught on board the exploration ship BIP XII had a similar dietary composition to those found in the shallow waters of Punta Lobos (14-40 m) where for both regions, the dominant prey items were the pelagic red crab and UOM. According to Levin's index, M. henlei may be a specialist feeder in this area. A diet overlap according to sex, area, and size was observed. The SIMPER analysis showed a low similarity in diet in relation to sex, size, and area. According to the ANOSIM test there were no significant differences. Knowing that $M$. henlei shows a specialist behavior could help research studies not only for species conservation but also for its habitat and the organisms that inhabit it, which are both of vital importance for this shark.
\end{abstract}

Key words: Stomach content, diet overlap, specialist, Punta Lobos, Baja California Sur, México

\section{INTRODUCTION}

In Mexican waters, about 80 shark species have been registered (Applegate et al. 1979); around 45 of those species inhabit the waters of the Gulf of California
(Galván-Magaña et al. 1989). Baja California Sur has a strong tradition in shark fishing because of its long coastline with protected and deep sea waters as well as 
being a transition zone between temperate and tropical areas (Bonfil et al. 1990). However, scarce reliable biological information on sharks in this area is one of the main problems hindering decision-making on the resource management of commercial priority fisheries and of those resources that are not exploited (Castro-Aguirre et al. 1999).

Mustelus henlei Gill, 1863, from the family Triakidae, is an abundant specie in temperate and tropical waters and very common in closed and shallow bays with muddy and sandy bottoms. The species occurs from northern California, U.S.A. to the Gulf of California, Ecuador, and Peru and constitutes a commercial resource in Mexico. The specie is small; average size ranges from $50 \mathrm{~cm}$ to 70 $\mathrm{cm}$; a maximum total length around $95 \mathrm{~cm}$; viviparous, with a yolk sac-placenta; 3 to 5 pups per litter; size at birth from $19 \mathrm{~cm}$ to $21 \mathrm{~cm}$; males and females reach sexual maturity at a size ranging from $51 \mathrm{~cm}$ and $63 \mathrm{~cm}$ (Fischer et al. 1995). Few studies on the diet of $M$. henlei have reported it feeds mainly on shrimp, crustaceans, fish (Russo 1975, Talent 1982, Gómez et al. 2003), and polychaetes (Haeseker \& Czech 1993). It is classified as a tertiary predator or mesopredator ( $\mathrm{TL}=3.6$ ) (Cortes 1999).

Up to date, there is no information on the feeding habits of $M$. henlei for the Mexican Pacific or the Gulf of California. Absence of information for these areas points out the need to improve knowledge of this species whose life strategy could be affected unfavorably by directed or incidental fishing emphasizing the value of planning marine conservation (Rojas 2006). Resource management planning must be based on research where there will be benefits for many countries according to their perspectives (Rodriguez-Romero et al. 2009).

Therefore, the aim of this study was to provide biological information about $M$. henlei for the western continental shelf of Baja California Sur, Mexico, to expand knowledge on its behavior, study size, sex, and geographical distribution and to determine its feeding strategies.

\section{Materials ANd Methods}

\section{STUDY AREA}

The western coast of Baja California Sur is directly exposed to the high-energy regime of the Pacific Ocean (Fig. 1). Constant wind direction is northeast from May to October and southeast from November to February. Along the peninsula, winds that come from the north and

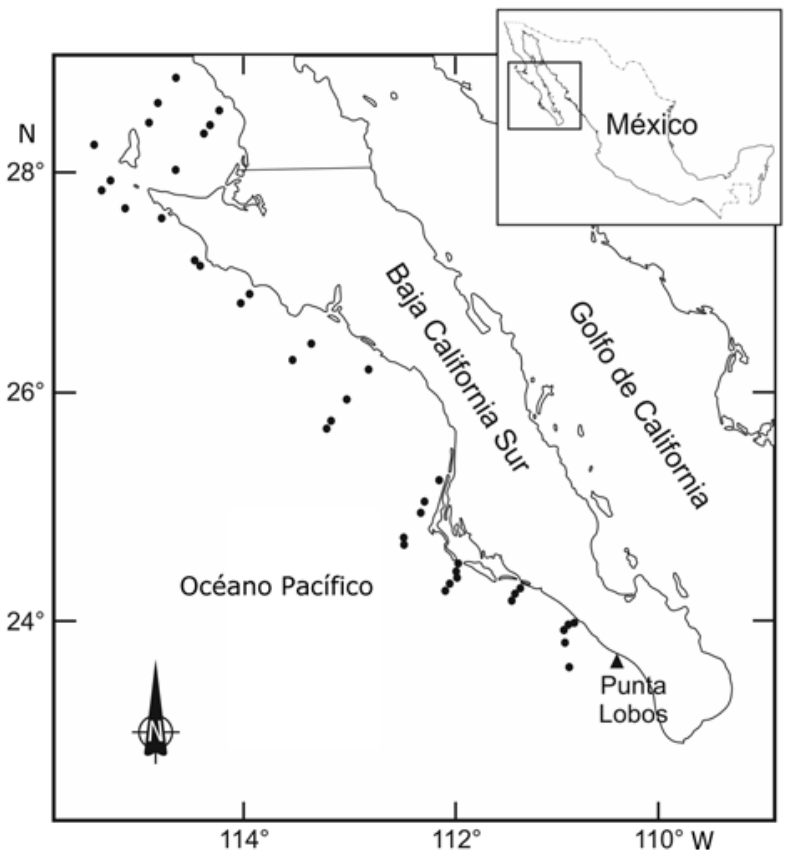

Figure 1. Sampling map for Mustelus henlei in the western coast of Baja California Sur, México. Black dots show the BIP XII exploration ship-sampling trajectory / Mapa de muestreo para Mustelus henlei en la costa Occidental de Baja California Sur, México. Los puntos negros señalan el trayecto de muestreo del barco BIP XII

northwest are vitally important to the ecosystem because they move the waters parallel to the coast, and together with the influence of the Earth's rotation, the wide cyclonic turns, surge fronts, and other effects provide nutrients to the superficial layer making it ideal for primary organic production (Rueda 1983).

\section{Data Collection}

Samples were obtained from a scientific cruise and coastal fishing activities in Punta Lobos. The first sampling was performed with shrimp trawling nets from 11 March to 3 April 2005 on board the fisheries exploration ship BIP-XII

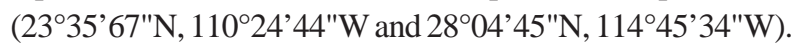
12 transects were established with a total of 55 hauls at an average depth of 30,100, and a maximum depth of 300 $\mathrm{m}$. Each trawl lasted from 15 to $20 \mathrm{~min}$ at a speed of

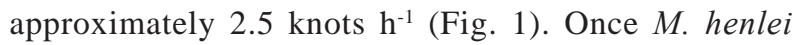
individuals were obtained, they were transferred to the Fisheries Ecology Laboratory at CIBNOR for stomach extraction and content analysis.

The second sampling was performed in Punta Lobos $\left(23^{\circ} 25^{\prime} \mathrm{N}, 110^{\circ} 14^{\prime} \mathrm{W}\right)$ on 17 and 18 June 2005 applying the same methodology with respect to sample collection. 
However, samples were captured with a 12.7-15.24 cm (56 in) monofilament mesh, which resulted in a more specific capture interval.

Total length (TL) was registered for each specimen captured using a conventional precision ichthyometer (1 m $\pm 1 \mathrm{~cm}$ ). Likewise, sex was determined, and stomachs were extracted and transported to the Fisheries Ecology Laboratory at CIBNOR, and frozen at $-25^{\circ} \mathrm{C}$ until they were analyzed. All the stomach samples were placed in $70 \%$ isopropyl alcohol, and the degree of gastric repletion was determined; then stomachs were grouped in 4 filling categories following Stillwell \& Kohler (1982), where $0=$ empty stomach: $1=25 \%$ filling; $2=50 \%$ filling; $3=75 \%$ filling; and $4=100 \%$ full.

From the stomach content, the different prey species were separated and classified according to their digestion stage. In the case of fish in a minimum digestion stage, identification keys were used according to Miller \& Lea (1972), Eschmeyer et al. (1983), Allen \& Robertson (1994), and Fischer et al. (1995); while for other fish in an advanced digestion stage, identification codes were used based on counting meristic characters (skeleton and vertebras) according to Clothier (1950) and Miller \& Jorgensen (1973); crustaceans were identified by keys based on external characteristics (Brusca 1980). Cephalopods were identified with codes based on Iverson \& Pinkas (1971); unidentified organic material (UOM) was also separated. Once different prey was separated, they were identified to the least possible taxon. Finally, the content was counted and weighed in an analytical balance $(2000 \pm 0.01 \mathrm{~g})$.

\section{QuANTITATIVE DIET COMPOSITION}

For the quantitative analysis of the stomach contents, percentage methods were utilized, such as numeric $(\% \mathrm{~N})$, gravimetric (\%W), and frequency of occurrence (\%FO) according to Hyslop (1980), as well as the index of relative importance $(\% \mathrm{IRI}=(\% \mathrm{~N}+\% \mathrm{~W}) \times \mathrm{\% FO})$ proposed by Cortés (1997).

\section{ECOLOGICAL INDEX}

Diet niche breadth was determined using Levin's standardized index (Krebs 1989), following the technique proposed by Labropoulou \& Eleftheriou (1997) using the following formula:

$$
B i=1 / n-1\left\{\left(1 / \sum j P i j^{2}\right)-1\right\}
$$

Where $B i=$ Levin's index for predator $j$; $P i j^{2}$ proportion of predator's diet $i$ on prey $j$, and $n=$ number of prey categories. These index values fluctuate from 0 to 1 ; under 0.6 indicates a diet dominated by few prey; thus, we are dealing with a specialist predator; values larger than 0.6 reveal diets of a generalist (Krebs 1989).

To analyze trophic overlap between areas (Punta Lobos and on board the exploration ship BIP XII), sizes (juveniles and adults) and sex, the Morisita-Horn index (Hyslop 1980) was used with the following equation:

$$
C_{i=l}^{n} \lambda=2 \sum(P x i \times P y i) /\left(P x i+\sum P_{i=l}^{n} i\right)
$$

Values $C \lambda$ ranged from 0 to 1 . We used Langton's (1982) scale, which defines that values 0-0.29 indicate a low overlap; 0.30-0.59 average overlap: and higher than 0.6 indicate a high overlap. When values of 1 are obtained, it means that all the elements in the diet are shared, indicating a total overlap.

\section{STATISTICAL ANALYSIS}

A completely at random design was used with a sample size of 166 organisms. For the stomach content analysis, one-way similarity test ANOSIM $(P<0.05)$ was utilized to determine differences by sex, size, and area. The test implies a global statistical calculus (R) that contrasts similarity variance within and among groups, considering values $\mathrm{R}>0.75$ imply a defined separation; $\mathrm{R}>0.50$ a clear differentiation; $\mathrm{R}>0.25$ a reduced separation; and $\mathrm{R} \sim 0$ a small or null separation (Clarke 1993, Clarke \& Warwick 2001). The last step was the application of a similarity percentage (SIMPER) test to determine which species contributed more to defining diet composition. These analyses were performed by using PRIMER V6.0 (Plymouth Routines in Marine Research Programs) (Clarke \& Warwick 2001).

\section{Results}

\section{Diet Composition OF MUSTELUS HENLEI}

Of the 166 individuals analyzed, 66\% showed stomach content. The TL of Mustelus henlei specimens fluctuated from $36 \mathrm{~cm}$ to $106 \mathrm{~cm}$. Following the filling proportion values: $45 \%$ of the stomachs were found within category 1 (0-25\% full); $12 \%$ within category 2 (26-50\% full); $22 \%$ in category 3 (51-75\% full); and 21\% in category 4 (76$100 \%$ full). A total of 24 types of prey were identified through a taxonomical analysis, of which 15 were 
Table 1. Percentages in numeric $(\% \mathrm{~N})$, gravimetric $(\% \mathrm{~W})$, frequency of occurrence (\%FO), and index of relative importance (\%IRI) methods of the general trophic spectrum of Mustelus henlei in the western portion of Baja California Sur / Porcentaje del espectro trófico general del tiburón Mustelus henlei en la porción Occidental de la Península de Baja California, en los métodos de porcentaje numérico $(\% \mathrm{~N})$, gravimétrico $(\% \mathrm{P})$, frecuencia de Ocurrencia (\%FO), e índice de importancia relativa (\%IIR)

\begin{tabular}{lrrrrl}
\hline Prey species & $\% \mathrm{~N}$ & $\% \mathrm{~W}$ & $\% \mathrm{FO}$ & $\% \mathrm{IRI}$ & Categories \\
\hline Crustaceans & & & & & \\
Galatheidae & 65.4 & 52.5 & 44.7 & 81.5 & Main \\
Stomatopoda & 3.2 & 0.1 & 12.8 & 0.2 & Secondary \\
Brachyura & 2.6 & 2.7 & 13.2 & 1.60 & Secondary \\
Calappidae & 0.2 & 0.3 & 0.8 & 0.01 & Occasionally \\
Portunidae & 1.4 & 7.2 & 34.4 & 0.60 & Occasionally \\
Anomura & 1.2 & 0.01 & 3.25 & 0.05 & Occasionally \\
Crustacean remains & 3.6 & 0.63 & 8.0 & 0.38 & Secondary \\
Mollusca & & & & & \\
Cephalopoda & 3.0 & 1.14 & 4.0 & 0.10 & Occasionally \\
Octopodidae & 0.24 & 0.27 & 0.88 & 0.004 & Occasionally \\
Osteichthyes & & & & & \\
Scombridae & 3.12 & 7.5 & 8.8 & 0.94 & Main \\
Scorpaenidae & 0.24 & 0.57 & 0.88 & 0.01 & Occasionally \\
Serranidae & 0.24 & 1.01 & 0.88 & 0.01 & Occasionally \\
Paralichthyidae & 0.24 & 1.69 & 0.88 & 0.02 & Occasionally \\
Uranoscopidae & 0.72 & 0.64 & 2.63 & 0.04 & Occasionally \\
Rest Fish & 3.12 & 4.8 & 10.5 & 0.84 & Main \\
UOM & 11.03 & 27.5 & 40.4 & 16.0 & Main \\
Benthic material & 0.72 & 0.06 & 2.6 & 0.02 & Occasionally \\
\hline & & & & & \\
\hline
\end{tabular}

crustaceans, 6 fish, and 3 cephalopods besides UOM (Table 1). According to \%IRI, crustaceans were the most important prey, where the pelagic red crab Pleuroncodes planipes, was the main prey, followed by UOM, Scomber japonicus, and fish remains.

According to the numeric method, a total of 417 prey organisms were counted, where crustaceans contributed $77.6 \%$, UOM $11.03 \%$, fish $7.6 \%$, and mollusks 2.8\% (Table 1 ). The most numerous type of prey was $P$. planipes, followed by crustacean remains and the mackerel $S$. japonicus. Prey total weight was $1330.6 \mathrm{~kg}$, with the contribution of crustaceans, UOM, fish, and mollusks. The rest of the prey did not have an important contribution, all together contributing less than $14 \%$.

\section{FEEDING HABITS AND ECOLOGICAL INDEX}

The total length recorded for females ranged from $36 \mathrm{~cm}$ to $102 \mathrm{~cm}$. The total number of stomachs analyzed for females was 103 (29 empty), where 18 prey species were found in their diet. On the other hand, males recorded a total length of $37 \mathrm{~cm}$ to $107 \mathrm{~cm}$. The total number of stomachs analyzed for males was 63 (23 empty). Their diet was composed of 14 types of prey. The most important prey content was $P$. planipes and UOM (Fig. 2). When determining trophic breadth by sex, a difference in values was observed, 0.06 for females and 0.09 for males (Fig. 5).

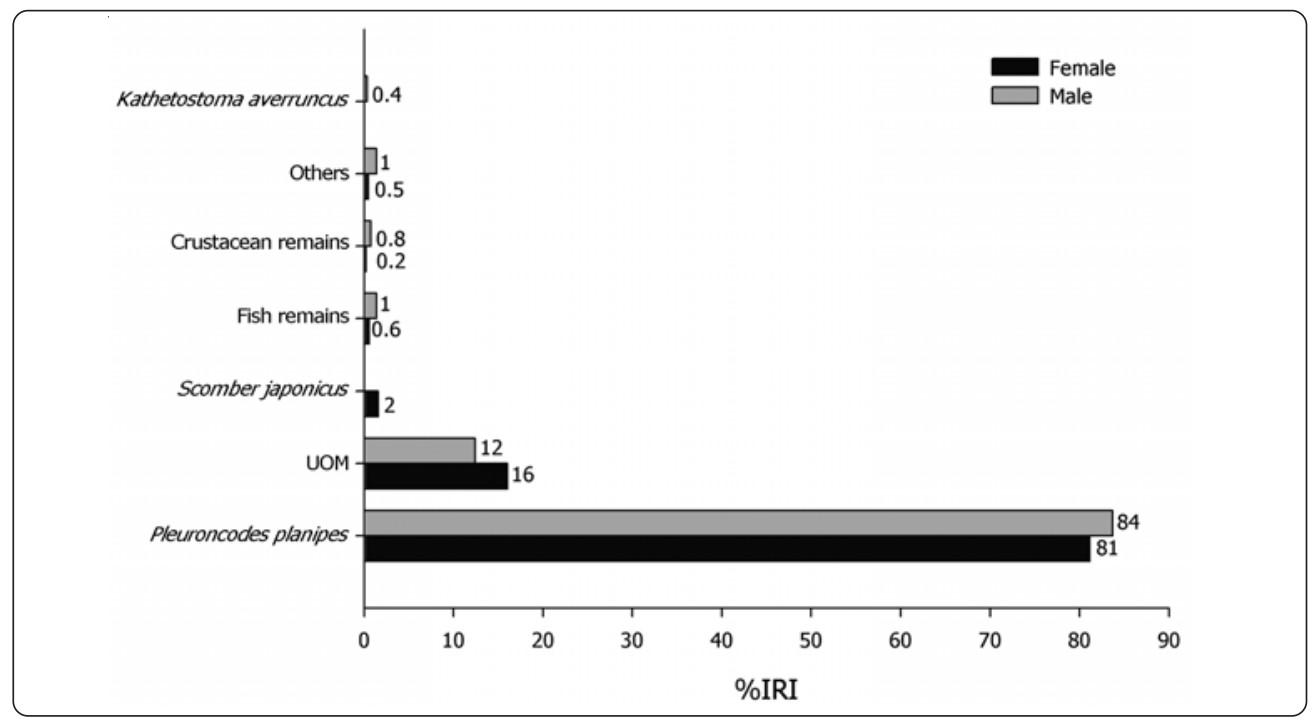

Figure 2. Index of relative importance (\%IRI) of the main prey for males and females of the shark Mustelus henlei in the western portion of Baja California Sur, México / Índice de importancia relativa (\%IIR), de las presas principales de machos y hembras del tiburón Mustelus henlei, en la porción Occidental de la Península de Baja California Sur, México 


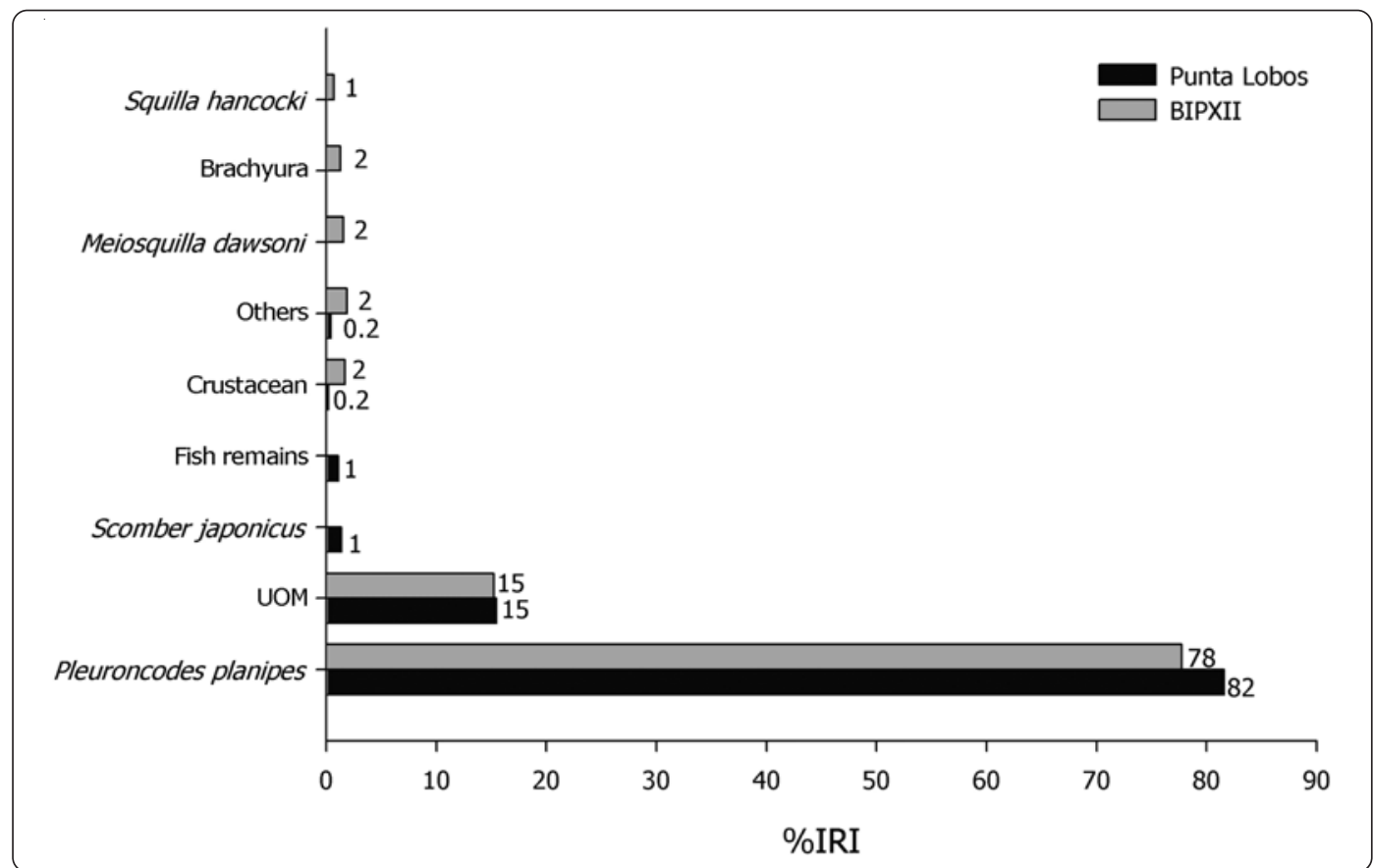

Figure 3. Index of relative importance (\%IRI) of the shark Mustelus henlei feeding habits in the coastal area of Punta Lobos and the deepest western portion of the Baja California Sur, México (Ship BIPXII) / Índice de importancia relativa (\%IIR), de los hábitos alimenticios del tiburón Mustelus henlei en la zona de Punta Lobos y en la zona más profunda de la porción Occidental de la Península de Baja California Sur, México (Barco BIPXII)

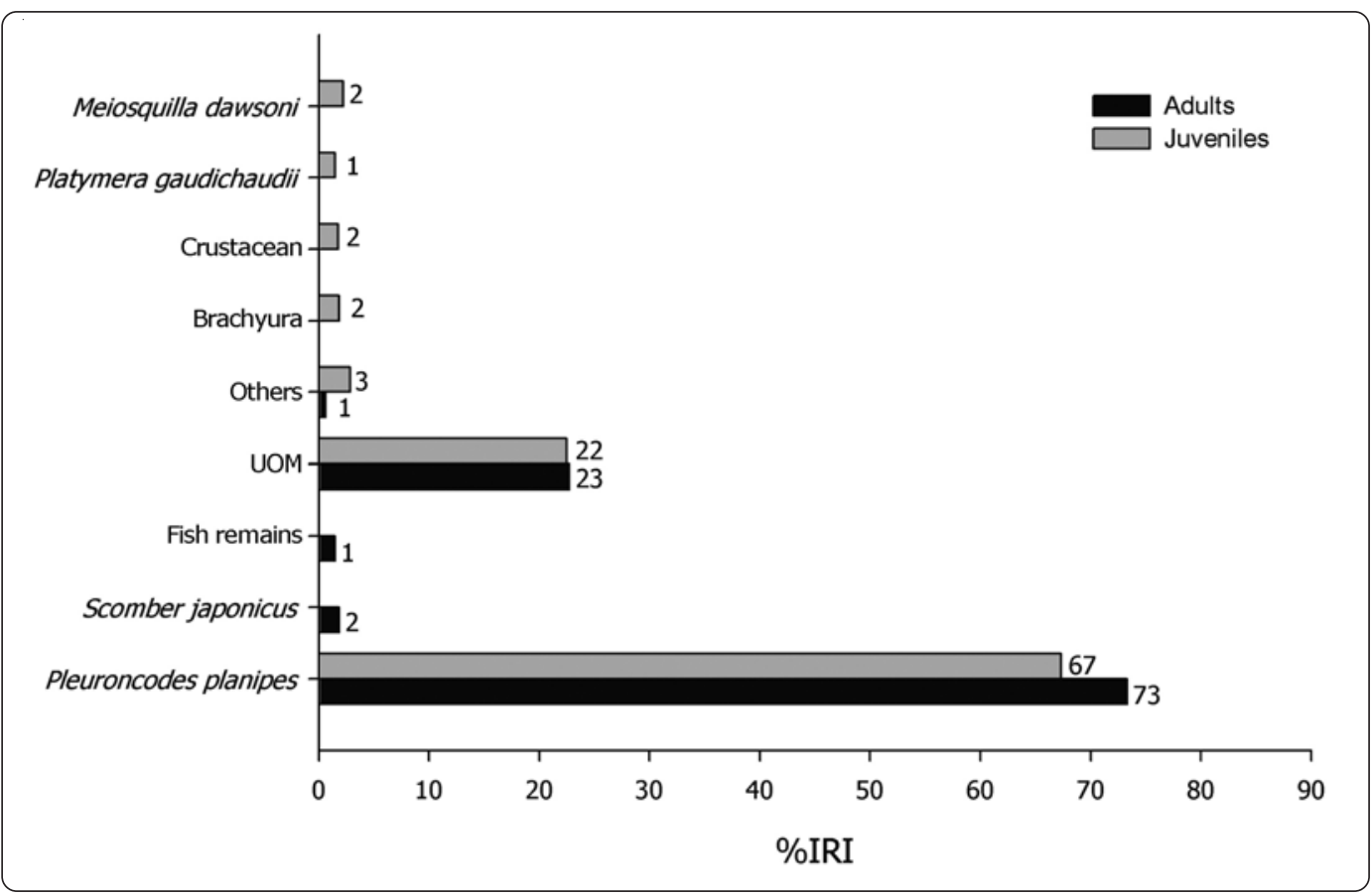

Figure 4. Index of relative importance (\%IRI) of the main prey for juveniles and adults of the shark Mustelus henlei in the western portion of Baja California Sur, México / Índice de importancia relativa (\%IIR), de las presas principales de juveniles y adultos del tiburón Mustelus henlei, en la porción Occidental de la Península de Baja California Sur, México 


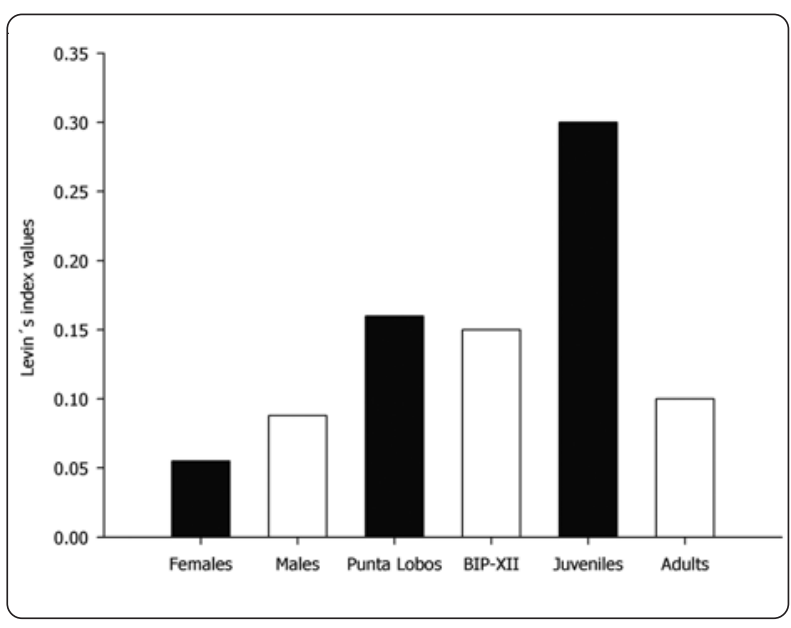

Figure 5. Trophic scope of the shark Mustelus henlei according to sex, sizes and sampling area in the western portion of Baja California Sur, México / Amplitud trófica del tiburón Mustelus henlei de acuerdo al sexo, talla y zona de muestreo en la porción Occidental de la Península de Baja California Sur, México

In Punta Lobos, a total of $101 \mathrm{M}$. henlei specimens (68 and 33 females and males (2:1), respectively) with lengths ranging from $58 \mathrm{~cm}$ to $106 \mathrm{~cm}$ were captured, of which 78 stomachs contained food. Through taxonomic analysis 19 types of prey were identified where the main ones were $P$. planipes, S. japonicus, and UOM (Fig. 3).

In the western portion off the Baja California Peninsula on board the exploration ship BIP XII, a total of 65 (31 females and 34 males) specimens with a length of 36-90 $\mathrm{cm}$ were collected of which only 36 had food in their stomachs. According to the \%IRI, 16 types of prey were identified through taxonomical analysis, of which the main types were $P$. planipes, crustacean remains, brachyurans, and UOM (Fig. 3). As to areas, we observed $B i$ values of 0.16 in Punta Lobos and $B i$ values of 0.15 on board BIPXII, considering the species as a specialist predator (Fig. 5).

For juveniles, TL was $36-61.5 \mathrm{~cm}$. The total number of stomachs analyzed was 62 (29 empty). The \%IRI showed preferences for P. planipes, Platymera gaudichaudii, Meiosquilla dawsoni, Brachyura, crustacean remains, and UOM.

For adults 104 stomachs were analyzed (22 empty); TL of these specimens ranged from 64 to $106 \mathrm{~cm}$. The most important prey in their diet was P. planipes, S. japonicus, fish remains, and UOM (Fig. 4). Levin's index showed juveniles $(B i=0.3)$ and adults $(B i=0.1)$ both having a specialist behavior (Fig. 5).

\section{DIET BREADTH AND OVERLAP OF MUSTELUS HENLEI}

Trophic breadth of Mustelus henlei in the western section of Baja California Sur was low ( $B i=0.05)$, showing a strong preference for some types of food; in this specific case the red pelagic crab (P. planipes) and the mackerel $(S$. japonicus). Thus, $M$. henlei may be considered as a specialist predator.

When comparing samples taken from deep to shallow water (BIP XII and Punta Lobos, respectively) we observed a high overlap of $\mathrm{Cl}=0.992$ between sexes and of $\mathrm{Cl}=0.949$ between areas according to Morisita-Horn's index. There was an evident overlap of $\mathrm{Cl}=0.862$ in juveniles and adults, indicating they have common prey and share a specific area of Pacific Ocean coast line.

\section{Statistical ANALYSIS}

By the SIMPER statistical analysis for females and males, we found that diets had a low similarity value (24\%) due to the variation in prey contribution percentage that mostly characterize their spectrum; likewise for juveniles and adults (21\%), as well as for Punta Lobos and on board BIP XII (22\%), which infers a reduced number of prey constitutes their diet (Table 2).

When applying the ANOSIM test by sex we did not find significant statistical differences $\left(R_{\text {global }}=0.065 ; P=\right.$ 0.2 ), only an overlap. Between juveniles and adults, we observed a reduced significant value $\left(R_{\text {global }}=0.177 ; P=\right.$ 1.0), likewise for the areas of Punta Lobos and on board $\operatorname{BIP~XII~}\left(R_{\text {global }}=0.20 ; P=0.1\right)$.

\section{Discussion}

In Mexico, the paternoster-line, hand line, and nets are the most used methods for commercial shark capture (Applegate et al. 1979). Coastal elasmobranchs, such as batoids and small sharks (cat sharks) are captured mainly with nets (Ramírez-Amaro 2011). When the shark is captured, the food ingested continues the digestive process and shows a high percentage of non-specific categories (items) as UOM, and fish and crustacean remains.

For $M$. henlei a small number of empty stomachs was found, as it has been reported in other studies where the percentage of empty stomachs in the species of the genus Mustelus is very low in general: $3.1 \%$ in $M$. griseus (Kamura \& Hashimoto 2004); 0.8\% in M. palumbes (Smale \& Compagno 1997); $2.47 \%$ in M. schmitti (Belleggia et al. 2012); 8.7-11.7\% in M. mustelus (Smale \& Compagno 1997, 
Table 2. Results of the SIMPER analysis (percentage similarities) by sexes, sizes, and areas for Mustelus henlei in the western coast of Baja California Sur, México / Resultados del analisis de SIMPER (porcentaje de similaridad) por sexos, tallas y areas para Mustelus henlei en la porcion Occidental de la Península de Baja California Sur, México

\begin{tabular}{|c|c|c|c|c|c|}
\hline & Group Female & Group Male & \multirow{2}{*}{$\begin{array}{c}\text { Dissimilarity } \\
\text { (mean) }\end{array}$} & \multirow{2}{*}{$\begin{array}{c}\text { Contribution } \\
(\%)\end{array}$} & \multirow{2}{*}{$\begin{array}{c}\text { Cumulative } \\
(\%)\end{array}$} \\
\hline & Abundance (mean) & Abundance (mean) & & & \\
\hline Pleuroncodes planipes & 1.82 & 1.43 & 26.4 & 34.77 & 34.77 \\
\hline UOM & 1.22 & 0.64 & 19.92 & 26.23 & 61.0 \\
\hline Scomber japonicus & 0.32 & 0.06 & 4.20 & 5.53 & 66.52 \\
\hline Rests Fish & 0.18 & 0.24 & 4.06 & 5.34 & 71.87 \\
\hline Brachyura & 0.02 & 0.16 & 3.59 & 4.73 & 76.6 \\
\hline Crustacean & 0.06 & 0.08 & 2.75 & 3.62 & 80.22 \\
\hline Platymera gaudichaudii & 0.05 & 0.07 & 2.01 & 2.64 & 82.86 \\
\hline Kathetostoma averruncus & 0.00 & 0.11 & 1.81 & 2.39 & 85.25 \\
\hline Clibanarius panamensis & 0.01 & 0.11 & 1.42 & 1.88 & 87.13 \\
\hline Solenocera florea & 0.02 & 0.03 & 1.22 & 1.61 & 88.73 \\
\hline Meiosquilla dawsoni & 0.02 & 0.04 & 1.16 & 1.53 & 90.26 \\
\hline \multicolumn{6}{|l|}{ Groups Females \& Males } \\
\hline \multicolumn{6}{|l|}{ Mean Similarity $=24 \%$} \\
\hline & Group Juvenil & Group Adult & Dissimilarity & Contribution & Cumulative \\
\hline & Abundance (mean) & Abundance (mean) & (mean) & $(\%)$ & $(\%)$ \\
\hline Pleuroncodes planipes & 0.85 & 2.0 & 28.04 & 35.37 & 35.37 \\
\hline UOM & 0.38 & 1.25 & 20.57 & 25.95 & 61.32 \\
\hline Scomber japonicus & 0.00 & 0.31 & 4.0 & 5.05 & 66.37 \\
\hline Brachyura & 0.13 & 0.06 & 3.73 & 4.71 & 71.08 \\
\hline Crustacean & 0.12 & 0.05 & 3.38 & 4.26 & 75.34 \\
\hline Fish remains & 0.00 & 0.28 & 3.17 & 4.0 & 79.34 \\
\hline Platymera gaudichaudii & 0.20 & 0.0 & 2.98 & 3.76 & 83.1 \\
\hline Kathetostoma averruncus & 0.08 & 0.03 & 1.76 & 2.22 & 85.32 \\
\hline Meiosquilla dawsoni & 0.11 & 0.0 & 1.71 & 2.16 & 87.48 \\
\hline Squilla hancocki & 0.07 & 0.0 & 1.4 & 1.77 & 89.24 \\
\hline \multicolumn{6}{|l|}{ Groups Juvenile \& Adult } \\
\hline \multicolumn{6}{|l|}{ Mean Similarity $=21 \%$} \\
\hline & Group Pta. Lobos & Group BIP XII & \multirow{2}{*}{$\begin{array}{c}\text { Dissimilarity } \\
\text { (mean) }\end{array}$} & \multirow{2}{*}{$\begin{array}{c}\text { Contribution } \\
(\%)\end{array}$} & \multirow{2}{*}{$\begin{array}{c}\text { Cumulative } \\
(\%)\end{array}$} \\
\hline & Abundance (mean) & Abundance (mean) & & & \\
\hline Pleuroncodes planipes & 2.12 & 0.87 & 29.12 & 37.23 & 37.23 \\
\hline UOM & 1.29 & 0.48 & 20.93 & 26.76 & 63.98 \\
\hline Scomber japonicus & 0.36 & 0.00 & 4.57 & 5.84 & 69.83 \\
\hline Fish remains & 0.28 & 0.03 & 3.39 & 4.33 & 74.16 \\
\hline Crustacean & 0.05 & 0.11 & 3.09 & 3.95 & 78.11 \\
\hline Brachyura & 0.00 & 0.14 & 2.91 & 3.73 & 81.84 \\
\hline Meiosquilla dawsoni & 0.02 & 0.07 & 1.57 & 2.01 & 83.85 \\
\hline Portumus xantussi & 0.00 & 0.11 & 1.53 & 1.96 & 85.81 \\
\hline Kathetostoma averruncus & 0.02 & 0.06 & 1.24 & 1.59 & 87.4 \\
\hline Stomatopoda & 0.01 & 0.04 & 0.91 & 1.17 & 90.03 \\
\hline \multicolumn{6}{|c|}{ Groups Pta. Lobos \& BIP XII } \\
\hline Mean Similarity $=22 \%$ & & & & & \\
\hline
\end{tabular}


Saïdi et al. 2009a); 8\% in M. antarticus (Yick et al. 2012); 13.7-14.28\% in M. punculatus (Jardas et al. 2007, Saïdi et al. 2009b, Lipej et al. 2011); 6\% in M. californicus (Talent 1982) and M. lunulatus (Navia et al. 2006); 5.5-14\% in $M$. henlei (Talent 1982, Haesker \& Czech 1993).

The occurrence of the high proportion of empty stomachs in other studies may be related to the use of long lines to capture animals (Wetherbee \& Cortés 2004), which may attract more animals with empty stomachs, such as $51.3 \%$ in M. canis (Vianna et al. 2000), 53.2\% in $M$. henlei, and 52.4\% in M. lunulatus (Gómez et al. 2003), and $38.22 \%$ in M. dorsalis (Rojas 2006).

The main food components found in M. henlei's trophic spectrum were $P$. planipes, a dominant pelagic species of great abundance and permanence on the continental shelf of Baja California Sur, which is associated with the California current system and distributes vertically along the water column (Boyd 1967); and secondly S. japonicus, an abundant fish in the pelagic coastal area, occasionally in the epipelagic area (Fischer et al. 1995). The majority of benthic organisms were stomatopods (Eurysquilla spp., Meiosquilla dawsoni, and Squilla hancoki) and brachyuran crabs. Demersal species defined as those that are closely related with the sea bottom either for reproduction or food, such as Kathetostoma averruncus were also registered.

In the central Seto Inland Sea of Japan, Kamura \& Hashimoto (2004) observed Mustelus griseus showing a preference for crabs living on sandy or muddy bottoms; Mustelus manazo prefers crustaceans and polychaets. In the Gulf of Nicoya, Costa Rica, Mustelus dorsalis is classified as a polyphagus opportunist predator for that area (Rojas 2006). Russo (1975) analyzed M. henlei finding it feeds mainly on the shrimps Upogebia pugettensis, Crago franciscorum and on crabs of the genus Cancer and Hemigrapsus oregonensis, species which establish intertidal feeding. He also found fish Cymatogaster aggregata, Engraulis mordax, and Citharicthys spp. in the guts. Talent (1982) concluded M. henlei feeds mainly on crustaceans, which are its most important feeding item; fish is the second most important prey for the largest sharks, and crustaceans are the most eaten in coastal shallow waters. Haesker \& Czech (1993) found M. henlei consumed more slender crabs and fish but fewer yellow shore crabs and polychaete worms than those near Indian Beach. Gómez et al. (2003) performed a study on the feeding habits of M. lunulatus and M. henlei in Gorgona National Natural Park in the Colombian Pacific, reporting these species generally predate on crustaceans, mainly Portunus iridiscens, Squilla panamensis and Hipoconcha panamensis, followed by mollusks of the family Loliginidae, and fish in less proportions.

The amplitude of the trophic niche in $M$. henlei necessarily implies a specialist food conduct; besides, pelagic, demersal, and benthic prey records suggest this organism performs vertical and horizontal migrations to make use of these types of prey ( $S$. japonicus and $P$. planipes). M. henlei's movements have been associated to tides, and this behavior could be explained by its feeding ecology, mainly that of an active forager on marshes (Campos et al. 2009). It remains in bays throughout the year but may leave them during winter as the waters cool and rains reduce salinity (Love 1996, Hopkins \& Cech 2003). At low tide Brown smooth hounds have generally retreated to deeper water where they may await their next foraging opportunity while digesting their last meal, thus exhibiting slower movement rates. They show a significant increase in movement during the night in relation to daytime (Campos et al. 2009), It could explain the high presence in their diet of $P$. planipes, which migrate vertically in the water column rising to the surface at dusk to feed and avoid predation (light intensity is less) and remain in this area during the night (Boyd 1967).

The presence of an important number of food components within the trophic spectrum of $M$. henlei makes its predation capacity evident. However, in spite of having a considerable number of prey, the trophic spectrum of this shark was very reduced, which is why it could be considered as a prey specialist by showing major consumption of only a few types of prey. Zayas-Álvarez (1998) mentioned that in elasmobranchs it is common to find a wider trophic spectrum in females than in males although there are no important differences. In our study females in general showed a low trophic spectrum (0.06), the same as for males. It highlights a narrow trophic spectrum, mainly due to the fact that both sexes feed on $P$. planipes and S. japonicus. The SIMPER analysis showed a low similarity percentage between prey percentages. According to the ANOSIM test there were no significant differences by sex that could have shown a diet overlay. The presence of common prey with different IRI percentages indicates there is no segregation by maturity stages; the results observed in females' diet could suggest they spend most of the time in the coastal area, feeding from benthic organisms (stomatopods and crustaceans) but frequently migrating toward the ocean area where pelagic red crab and mackerel can be observed. 
They are likely subjected to food availability in deeper waters. Males showed they feed on demersal and pelagic fish. Rojas (2006) points out that M. dorsalis could form ontogenic aggregations where females and males of similar sizes coincide spatially and temporally in feeding reserves very close to the bottom and near the coast. Regarding food site selection as reported by Pittenger (1984) regarding food site selection, these shark species could share space when finding sites where food is abundant and available.

The sharks found in the western section off the Baja California Peninsula on board (BIP-XII) and in Punta Lobos showed a specialist behavior, a high overlap between the diets, a low similarity of species abundance, and a significantly reduced difference. These results might be due to the high percentage of $P$. planipes consumption and the presence of UOM, which was difficult to separate and locate within the identified taxa because of their high degree of digestion. However, the sharks also showed other types of prey such as $S$. japonicus, crustacean remains, and brachyurans, which make a slight variation in $M$. henlei's diet according to area

Most of the juvenile sharks were found in deep waters (120-150 m), inferring they move between the ocean and coastal areas to feed on benthic organisms (brachyurans and squillas), as well as pelagic prey (P. planipes). The majority of the adults were captured in Punta Lobos (15$40 \mathrm{~m}$ ), most of them females, suggesting they move to coastal areas for reproductive purposes. Silva-Santos (2012) in his reproduction study on $M$. henlei on the western coast off Baja California Sur reports more adult females in the captures from the same area, possibly due to the breeding and birth season. Likewise with $M$. schmitti, the adults of both sexes were recorded in the coastal area because they prefer the warmer waters of spring and summer during breeding and birth (Oddone et al. 2007). The lesser proportion of juveniles in the adult capture sites confirms an ontogenic spatial separation. Embryos, newborn, and juveniles possibly occur in different growth areas, a condition that from the evolutionary viewpoint could be an advantage, as suggested by Branstetter (1990), who adds this separation reduces predation risk. The trophic width by size classifies $M$. henlei as a specialist, with a high overlay and a low similarity in diet, and a reduced significant difference likely linked to the consumption of $P$. planipes and UOM in a greater proportion. Fish and invertebrates were the most outstanding where the invertebrate P.planipes accounted for the difference in the abundance of $M$. henlei for some areas, justifying the importance these resources have to sustain different species by providing large benefits from the ecological and fishing point of view.

Fisheries have also made these species a target, which is why some shark populations have collapsed or have decreased in a short period of time (Anderson 1990). The combination of late maturity, low fecundity, and slow growth in most shark species has made them especially vulnerable to over-exploitation, and shark populations around the world are declining at a rapid rate due to overfishing (Musick 1999).

It is important to highlight that our study provides new information on $M$. henlei's diet as a benthic species dependent on the bento-pelagic habitat for feeding; it is a polyphagus organism that shows a strong preference for a small group of prey along the coasts of Baja California Sur. Knowledge on $M$. henlei's feeding habits and behavior as a specialist predator in this area will direct us toward better management of this species and its habitat.

\section{ACKNOWLEDGMENTS}

We are thankful for the support of the Project SAGARPACONACYT -2003-C01-179 'Distribución, abundancia y evaluación del potencial pesquero de la ictiofauna bénticodemersal en la plataforma continental de la costa occidental de la Península de Baja California'; additional funding was granted to the Laboratory of Fish Ecology from CIBNOR S.C.; to Diana Dorantes for translation, edition, and comments, and to Rubén Zepeda, undergraduate student, for his support in improving the map.

\section{LITERATURE CITED}

Allen G \& D Robertson. 1994. Peces del Pacífico Oriental Tropical, 327 pp. CONABIO, Agrupación Sierra Madre y CEMEX, México.

Anderson D. 1990. Fishery models as applied to elasmobranch fisheries. In: Pratt HL, Gruber SH \& T Taniuchi (eds). Elasmobranchs as living resources: Advances in the biology, ecology, systematics, and the status of fisheries. NOAA Technical Report NMFS 90: 473-484.

Applegate S, L Espinosa-Arrubarrena, L Menchaca-López \& F Sotelo-Macías. 1979. Tiburones mexicanos, 146 pp. Secretaría de Educación Pública, Subsecretaría de Educación e Investigación Tecnológicas, Dirección General de Ciencia y Tecnología del Mar, México.

Belleggia M, D Figueroa, F Sanchez \& C Bremec. 2012. The feeding ecology of Mustelus schmitti in the Southwestern Atlantic: dietary shifts and geographic variations. Environmental Biology of Fishes 95: 99-114. 
Bonfil R, F De Anda \& A Mena. 1990. Shark fisheries in México: The case of Yucatan as an example. In: Pratt HL, Gruber SH \& T Taniuchi (eds). Elasmobranch as living resources: advances in the biology, ecology, systematics, and the status of the fisheries. NOAA Technical Report NMFS 90: 1-518.

Boyd M. 1967. Benthic and pelagic habitats of the red crabs Pleuroncodes planipes. Pacific Science 21(3): 394-403.

Branstetter S. 1990. Early life history implications of selected Carcharhinoid and Lamnoid sharks of the northwest Atlantic. NOAA Technical Reports NMFS 33: 17-28.

Brusca RC. 1980. Common intertidal in invertebrates of the Gulf of California, 513 pp. The University of Arizona Press, Tucson.

Campos BR, MA Fish, G Jones, RW Riley, PJ Allen, PA Klimley, JJ Cech \& JT Kelly. 2009. Movements of brown smooth-hounds, Mustelus henlei, in Tomales Bay, California. Environmental Biology of Fishes 85: 3-13.

Castro-Aguirre J, C Woodley \& R Brudek. 1999. A preliminary evaluation of the status of shark species. FAO Fisheries Technical Paper 380: 1-72.

Clarke KR. 1993. Non-parametric multivariate analyses of changes in community structure. Australian Journal of Ecology 18: 117-143.

Clarke KR \& RM Warwick. 1994. Change in marine communities: an approach to statistical analysis and interpretation, 144 pp. Plymouth Natural Environment Research Council, Plymouth.

Clarke KR \& RM Warwick. 2001. Primer v6: User manual/ tutorial, 91 pp. Primer-E, Plymouth Marine Laboratory, Plymouth.

Clothier C. 1950. A key to some Southern California fishes based on vertebral characters. Department of Natural Resources. Division of Fish and Game, Fish Bulletin 79: 1-83.

Cortés E. 1997. A critical review of methods of studying fish feeding based on analysis of stomach contents: application to elasmobranch fishes. Canadian Journal of Fisheries and Aquatic Sciences 54: 726-738.

Cortes E. 1999. Standardized diet compositions and trophic levels of sharks. ICES Journal of Marine Science 56: 707-717.

Eschmeyer W, S Herald \& H Hamman. 1983. Pacific coast fisher, 367 pp. Mifflin Co. Boston, Houghton.

Fischer W, F Krupp, W Schneider, C Sommer, K Carpenter \& H Niem. 1995. Guía FAO para la identificación de peces para los fines de pesca. Pacífico Centro-Oriental. Vol. II y III. Vertebrados, Parte 1 y 2: 647-1813.

Galván-Magaña F, H Nienhuis \& P Klimley. 1989. Seasonal abundance and feeding habits of sharks of the lower Gulf of California. Mexico. California Fish and Game 75: 74-84.

Gómez G, L Zapata, R Franke \& G Ramos. 2003. Hábitos alimentarios de Mustelus lunulatus y M. henlei (Pisces: Triakidae) colectados en el Parque Nacional Natural Gorgona, Pacífico Colombiano. Boletín de Investigación Marina Costera 32: 219-229.
Haesker L \& J Czech. 1993. Food habits of the brown smoothhound shark (Mustelus henlei) from two sites in Tomales Bay. California Department of Fish and Game 79(3): 89-95.

Hopkins TE \& JJ Cech Jr. 2003. The influence of environmental variables on the distribution and abundance of three elasmobranches in Tomales Bay, California. Environmental Biology of Fishes 66: 279-291.

Hyslop E. 1980. Stomach contents analysis a review of methods and their application. Journal of Fish Biology 17: 411-429.

Iverson K \& L Pinkas. 1971. A pictorial guide to beak of certain eastern Pacific cephalopods. Fishery Bulletin 152: 83-105.

Jardas I, M Santic, V Nerlovic \& A Pallaoro. 2007. Diet composition of blackspotted smoothhound, Mustelus punctulatus (Risso, 1826), in the eastern Adriatic Sea. Journal of Applied Ichthyology 23: 279-281.

Kamura S \& H Hashimoto. 2004. The food habits of four species of triakidae sharks, Triakis scyllium, Hemitriakis japanica, Mustelus griseus and Mustelus manazo, in the central Seto Inland Sea, Japan. Fisheries Science 70: 10191035.

Krebs J. 1989. Ecological methodology, 550 pp. Harper and Row, New York.

Langton W. 1982. Diet overlap between the Atlantic cod, Gadus morhua, silver hake Merluccius bilinearis, and fifteen other northwest Atlantic finfish. Fishery Bulletin 80: 754-759.

Lapropoulou M \& A Eleftheriou. 1997. The foraging ecology of two pairs of congeneric demersal fish species: importance of morphological characteristics in prey selection: Journal Fish Biology 50: 324-340.

Lipej L, B Mavric, S Resek, M Chérif \& C Capapé. 2011. Food and feeding habits of the blackspotted smooth-hound, Mustelus punctulatus (Elasmobranchii: Carcharhiniformes: Triakidae), from the Northern Adriatic. Acta Ichthyologica et Piscatoria 41: 171-177.

Love M. 1996. Probably more than you want to know about the fishes of the Pacific coast, 381 pp. Really Big Press, Santa Barbara

Miller DJ \& RN Lea. 1972. Guide to the coastal marine fishes of California. California Department of Fish and Game Bulletin 157: 1-249.

Miller J \& C Jorgensen. 1973. Meristic characters of some marine fishes of the western Atlantic Ocean. Fishery Bulletin 71(1): 301-312.

Musick JA. 1999. Ecology and conservation of long-lived marine animals. In: Musick JA (ed). Life in the slow lane: Ecology and conservation of long-lived marine animals. American Fisheries Society Symposium, 23 pp. American Fisheries Society, Bethesda.

Navia AF, A Giraldo \& PA Mejía-Falla. 2006. Notas sobre la biología y dieta del toyo vieja (Mustelus lunulatus) en la zona central de pesca del Pacífico colombiano. Investigaciones Marinas 34: 217-222. 
Oddone MC, L Paesch, W Norbis \& G Velasco. 2007. Population structure distribution and abundance patterns of the Patagonian smoothhound Mustelus schmitti Springer, 1939 (Chondrichthyes, Elasmobranchii, Triakidae) in the Rio de la Plata and inner Continental Shelf, SW Atlantic Ocean (34 $\left.30-39^{\circ} 30 S\right)$. Brazilian Journal of Oceanography 55(3): 167-177.

Pittenger G. 1984. Movements, distributions, feeding and growth of the pacific angel shark, Squatina californica off Santa Barbara, California. Copeia 1986: 987-994.

Ramirez-Amaro SR. 2011. Caracterización de la pesqueria artesanal de elasmobranquios en la Costa Occidental de Baja California Sur, México. Tesis de Maestria, Centro Intedisciplinario de Ciencias Marinas (CICIMAR-IPN), La Paz, 110 pp.

Rodríguez-Romero J, S Hernández-Vázquez \& J LópezMartínez. 2009. Desarrollo potencial de peces desaprovechados. Ciencia y Desarrollo 35: 45-51.

Rojas J. 2006. Reproducción y alimentación del tiburón enano Mustelus dorsalis (Pisces: Triakidae) en el Golfo de Nicoya, Costa Rica: Elementos para un manejo sostenible. Revista de Biología Tropical 54(3): 861-871.

Rueda F. 1983. La precipitación como indicador de variación climática en la Península de Baja California y su relación dendocronológica. Tesis de Maestría, Centro Interdisciplinario de Ciencias Marinas, Instituto Politécnico Nacional, La Paz, 125 pp.

Russo A. 1975. Observations on the food habits of leopard sharks (Triakis semifasciata) and brown smoothhounds (Mustelus henlei). California Department of Fish and Game 61(2): 5-103.

Saïdi B, S Enajjar, MN Bradaï \& A Bouaïn. 2009a. Diet composition of smooth-hound shark, Mustelus mustelus (Linnaeus, 1758), in the Gulf of Gabès, southern Tunisia. Journal of Applied Ichthyology 25: 113-118.

Saïdi B, MN Bradaï \& A Bouaïn. 2009b. Reproductive biology and diet of Mustelus punctulatus (Risso, 1826) (Chondrichthyes: Triakidae) from the Gulf of Gabès, central Mediterranean Sea. Scientia Marina 72: 249-258.
Silva-Santos JR. 2012. Biología reproductiva del tiburón mamón pardo Mustelus henlei (Gill, 1863) en la Costa Occidental de Baja California Sur, México. Tesis de Maestria, Centro Interdisciplinarios de Ciencias Marinas (CICIMAR-IPN), La Paz, 110 pp.

Smale M \& L Compagno. 1997. Life history and diet of two southern African smoothhound sharks, Mustelus mustelus (Linnaeus, 1758) and Mustelus palumbes Smith, 1957 (Pisces: Triakidae). South African Journal of Marine Science 18: 229-248.

Stillwell E \& E Kohler. 1982. Food, feeding habits and estimates of daily ration of the shortfin mako (Isurus oxyrinchus) in the Northwest Atlantic. Canadian Journal of Fisheries Aquatic Sciences 39: 407-414.

Talent L. 1982. Food habits of the gray smoothhound, Mustelus californicus, the brown-smoothhound, Mustelus henlei, the shovelnose guitarfish, Rhinobatos productus, and the bat ray, Myliobatus californica, in Elkhorn Slough, California. California Fish and Game 68: 224-234.

Vianna M, CA Arfelli \& AF Amorim. 2000. Feeding of Mustelus canis (Elasmobranchii, Triakidae) caught off southsoutheast coast of Brazil. Boletim do Instituto de Pesca 26: $79-84$

Wetherbee BM \& E Cortés. 2004. Food consumption and feeding habits. In: Carrier JC, JA Musick \& MR Heithaus (eds). Biology of sharks and their relatives, pp. 223-244. CRC Press, Boca Raton.

Yick JL, A Barnett \& S Tracey. 2012. The trophic ecology of two abundant mesopredators in south-east coastal waters of Tasmania, Australia. Marine Biology 159: 1183-1196.

Zayas-Álvarez A. 1998. Biología reproductiva del tiburón ángel Squatina californica (Ayres, 1859) (Pisces: Squatinidae) en el Golfo de California. Tesis de Licenciatura, Universidad Autónoma de Baja California Sur, La Paz, 49 pp. 